\title{
ENZYME BIOCATALYSIS IN ORGANIC SYNTHESIS
}

\author{
YASEEN $\mathrm{F}^{1^{*}}$, SIDDIQUE $\mathrm{A}^{2}$, IDREES $\mathrm{N}^{2}$, FATEH $\mathrm{A}^{2}, \operatorname{AHMAD~} \mathrm{R}^{3^{*}}, \operatorname{ALI} \mathrm{A}^{3}, \operatorname{ALI} \mathrm{I}^{3 *}$ \\ ${ }^{I}$ Department of Biotechnology, University of Central Punjab, Lahore, Pakistan \\ ${ }^{2}$ Institute of Molecular Biology and Biotechnology (IMBB), The University of Lahore, Lahore, Pakistan. \\ ${ }^{3}$ Department of Microbiology and Molecular Genetics, University of Okara, Okara Pakistan \\ "Corresponding author email: fatimayaseen26@gmail.com, rubabsandhu83@gmail.com, \\ chamdadalijutt786@gmail.com
}

(Received, $11^{\text {th }}$ January 2021, Revised $20^{\text {th }}$ June 2021, Published $24^{\text {th }}$ June 2021)

\begin{abstract}
The factor that makes enzyme biocatalysts for organic synthesis both fascinating and challenging from a scientific standpoint is the field's higher interdisciplinarity, and which necessitates expertise from a wide range of disciplines, including microbiology, organic synthesis, molecular biology, genetics, and reaction engineering. Enzymes can now carry out a wide variety of organic reactions, including hydrolytic reactions, redox reactions, and $C$-C bond formations, with higher performance. Enzyme catalysis has also evolved into a widely used manufacturing technology in the chemical industry, especially in the fields of fine organic chemicals and pharmaceuticals. More advances in molecular modeling for enzyme-catalysis syntheses are expected, allowing for a greater number of biocatalytic techniques based on the enzymes that have been optimized or engineered by rationalized protein engineering. The organic chemists mostly have successfully used these custom-made biocatalysts (the isolated pure enzymes, the recombinant genetically modified microorganisms, also known as the designer cells), an important milestone in the enzyme catalysis process in organic synthesis is into generally accepted synthetic technology for academia as well as industries.
\end{abstract}

Keywords: enzymes, catalyzed, organic reaction, pharmaceuticals, recombinant microorganisms

\section{Introduction}

Enzyme catalysis for organic synthesis technique is widely used in the preparation of organic chemical compounds at an academic and industrial scale as well. For various molecules, the artificial routes supported enzyme chemical process have clothed more competitive and excellent as compared to classic methods (Greoger, 2010; Fischer, 1894). Thus, an enzymatic chemical process is progressively recognized by organic chemists in each domain and business as a beneficial item. Enzymes can be used in different chemical reactions and transformations. For long ago the enzymatic catalysis processes were not commonly used as the first-choice for organic biosynthesis. The chemists have never used enzymes in biocatalysis because of their organic reactions as already known demerits, such as less the lower stability of the enzymes during organic chemical reaction conditions, substrate range, and the lower efficiencies (Boester et al., 1997; Drauz et al., 2012). However, the tremendous progresses and improvements for enzyme discoveries, advancing engineerings, and method for the development of enzymes, during recent years, there are numerous samples for the organic syntheses using enzymes have been developed which just ignore and overcome disadvantages.

The all of achievements and discoveries in microbiology, biotechnology, and molecular biology are because of the widely used enzymes in different processes due to their tremendous efficiency (Chenault et al., 1988; Marulanda et al., 2019). Enzymes are prepared at a favorable economic rate. The high efficiency of enzymes leads to the development of organic products. Chemists used enzymes in chemical processes at the industrial level for higher productivity.

\section{Structure of catalytic enzymes}

Three-dimensional structure of proteinslenzymes is included; the primary structure of polypeptide chain polypeptides, the secondary structures in proteins include $\alpha$-helix and $\beta$-sheet, andthe tertiary structure. The distinctive functions of the enzymes like catalytically active peptids as well as the proteins are because of their highly complex three-dimensional (3D) structures, and also fitting or attachment of active sites in that structure (Figure 1). This enables an extremely specific recognition of specific substrates, resulting in glorious selectivity's i.e., chemoselectivity and stereoselectivity (Pera et al., 2015; May et al., 2002). 


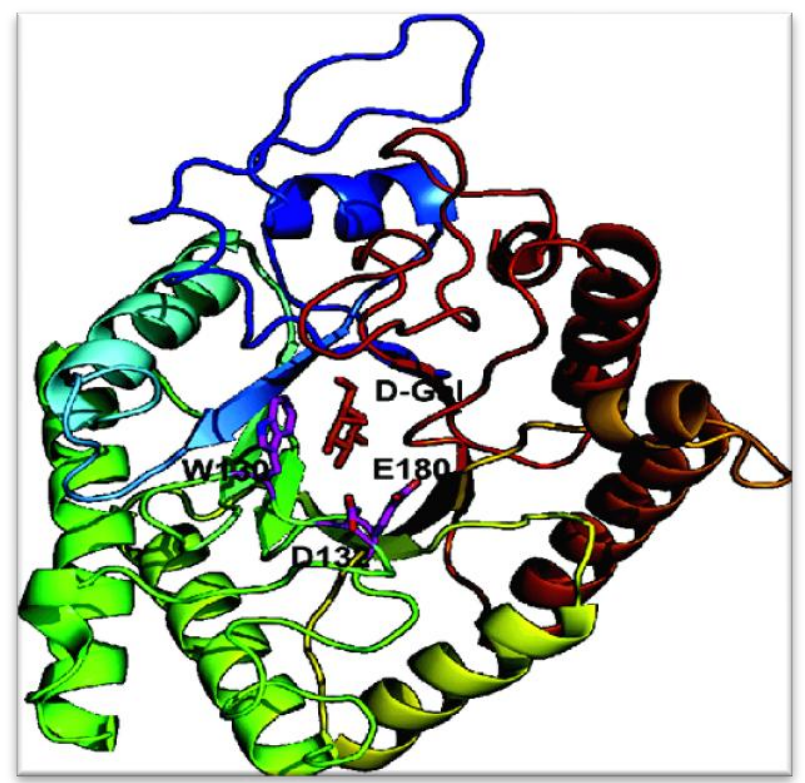

Figure 1. The three dimensional structure of the enzyme catalysis

General Properties of enzymes catalysis

Fischer found the lock-and-key model of the 3D enzymes which describes that the substrate fits or adjusts in the active site of the enzymes same as the key fits in the lock. All the enzymes are specific. They are reversible i.e., the enzymes bind with the substrates at its active site and forms the enzymesubstrate complex, then its produces product and release the enzyme for further reaction (Greoger et al., 2006; Lange et al., 2017). Enzymes activity requires favorable conditions like the temperature as well as $\mathrm{pH}$. The enzymes usually work at the neutral acidic and basic condition and the $\mathrm{pH}$ is mostly 5 to 10.

\section{Cofactor and Coenzymes}

The cofactors are usually the non-coded compounds which are essential for catalysis by enzyme they are attached to the enzyme either covalently or noncovalently. When a cofactor is formally attached to enzyme covalently this is so called as a prosthetic group. And in a non-covalent bond, a cofactor is attached to the enzyme it is also called as a coenzyme. Cofactors and coenzymes are used in the catalysis of enzymes for organic synthesis (Kataoka et al., 2003; Paul et al., 2019).

\section{Application}

Except for hydrolases, all enzyme classes manifest cofactor reliance. However, in some cases, for example, lyases cofactors are not essentially used in organic catalytic activity. Cofactors regenerate themselves in the form of NADP AND NADPH (Used in the redox process)

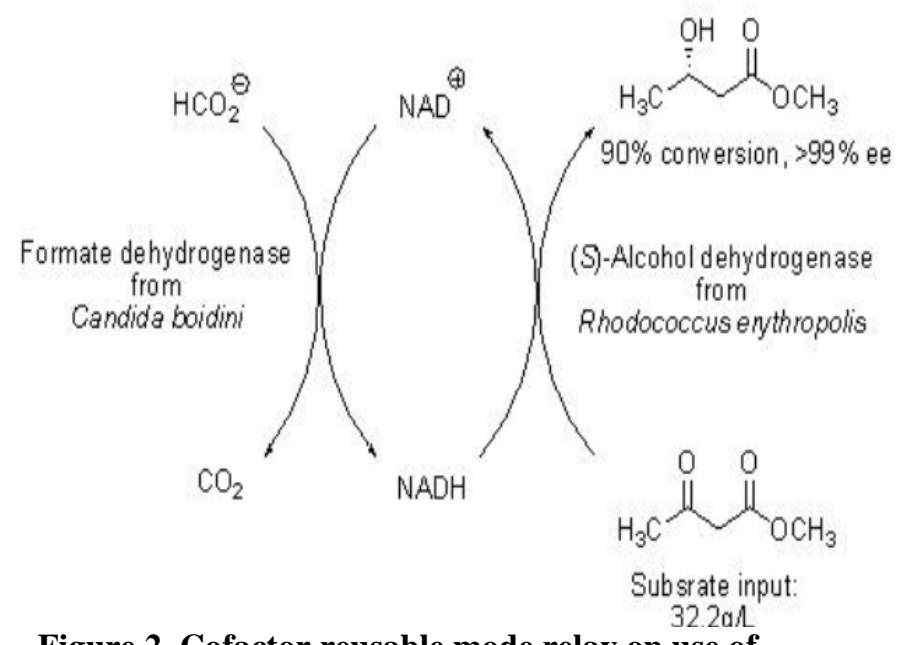

Figure 2. Cofactor reusable mode relay on use of formate dehydrogenase (reductive region)

The reducing agent in this reduction process is $\mathrm{NAD}(\mathrm{P}) \mathrm{h}$, a stoichiometric amount for these molecules would not let us do this catalytic synthesis (Figure 2), so by overcoming these problems. in situ cofactors regenerate the cofactor so that they can be used successfully in synthetic catalysis. To make the process cheap cofactor regenerates economically in the second enzymatic process (Silva et al., 2015; Kizaki et al., 2003).

Cofactor reused mode relay on $\mathrm{NAD}(\mathrm{p}) \mathrm{H}$ oxidase (oxidative region )

In this reaction, the substrate used in a stoichiometric amount, the stoichiometric oxidizing agent is $\mathrm{O}_{2}$. Cofactor restoration has been effectively evolved also electrochemically and chemocatalytic reactions developed enormously (Galkin et al., 1997; Greoger et al., 2010).

Examples of enzymatic catalysis in organic synthesis

Enzymatic synthesis catalysis is used in sweetener aspartame and semisynthetic antibiotics like amoxicillin, cephalexin, ampicillin, etc. Reduction of aldehyde is performed by using aldehyde dehydrogenase. In enantioselective acylation (catalyst: candida Antarctica lipase) of phenylethylamine with pentanoic acid.

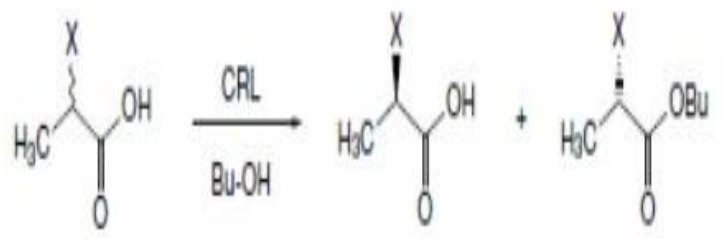

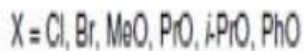

Figure 3. Reduction of aldehyde is performed by using aldehyde dehydrogenase 
The process of alcoholysis in vinyl cinnamate and benzyl alcohol (catalyst used in this process is PEG lipase). In process of esterification of propanoic acid and butanol (catalyst used in this process is CRL candida rugosa lipase). In the organic synthesis of enzymatic catalysis, biotechnological reactions take place in which transformation of the water-insoluble substrate into non-aqueous media occurred (Delimanto, 2020; Suresh et al., 2021). Mixing, sniping, and transfer of mass done efficiently by using lipase catalyst (transesterification, esterification, and suspension). Aldo ketoreductase enzyme catalyst used for the asymmetric aldol reaction. There are also many big achievements in the synthesis of biodiesel by enzymatic catalytic activity (Aui et al., 2021; Drauz et al., 2012). Lipase efficiently does the transformation work of triglycerides and then it is attractively used in the biodiesel industry. Hence, the use of enzymes in organic synthesis is adhesively used in the field of conversion selectivity and yield.

\section{Factor Affecting Enzymatic Reaction}

In the presence of the organic solvents, many enzymes are readily denatured and inactivated. As a result, protein engineering and a variety of physical and biochemical processes for stabilizing the enzymes in presence of the organic solvents, like immobilization, entrapment, and alteration, have been established (Hollmann et al., 2011; De Wildeman et al., 2007). Before going over the benefits and disadvantages of using the enzymes as biocatalysts in the organic synthesis processes (Table 1 ), a short rundown of some of the parameters for selecting a particular synthetic processes (based on chemo- or biocatalysts, like, classic resolutions for shaping diastereomeric salt pairs) is given.

Table 1. Advantages and disadvantages of enzymatic activities

\begin{tabular}{|c|c|}
\hline Advantages & Disadvantages \\
\hline $\begin{array}{l}\text { Improved enzyme } \\
\text { activity, selectivity, and } \\
\text { stability. }\end{array}$ & $\begin{array}{llr}\text { ILs that are } & \text { both } \\
\text { renewable } & \text { and } \\
\text { biodegradable } & & \end{array}$ \\
\hline $\begin{array}{l}\text { Offers new non-aqueous } \\
\text { enzymology options } \\
\text { with high quality. }\end{array}$ & $\begin{array}{l}\text { Product separation needs } \\
\text { to be improved }\end{array}$ \\
\hline $\begin{array}{l}\text { ILs or aqueous-IL } \\
\text { mixtures are tolerated } \\
\text { by a wide range of } \\
\text { enzymes. }\end{array}$ & $\begin{array}{l}\text { Ionic liquids must be } \\
\text { reused and purified } \\
\text { efficiently to preserve } \\
\text { their 'greenness' in } \\
\text { industrial applications. }\end{array}$ \\
\hline $\begin{array}{lcr}\text { Polar } & \text { non-volatile } \\
\text { materials } & \text { are a } \\
\text { specialty. } & & \end{array}$ & \\
\hline
\end{tabular}

amount of the substrates while also making downstream processing easier. This is especially true in reactions where the substrate as well as product have similar properties, such as similar boiling points, making separation difficult. In terms of enantioselectivity, the resulting product should have a higher enantiomeric excess of $>99$ percent e.e. (as specified by the FDA in chiral drugs). To achieve economically attractive volumetric productivities during the technical production methods, a substrate input of $>100$ gll (in general, optionally added in portions) is desirable.

Enzymes have a huge benefit as catalysts in organic synthesis. The presence of high enantioselectivity is also normal in Enantioselectivities often surpass Evalues in enzymatic resolution processes a hundred percent In regio- and stereoselectivities, higher to the excellent stereoselectivities which have been reported enzymatic reactions that are diastereoselective, and so on (Hall and Bommarius, 2011). Even when wildtype enzymes have unsatisfactory stereoselectivity, many protein engineering technologies exist which have already been proven to be successful in improving enzymatic efficiency in many cases. The enzymes are very interesting biocatalysts which fill a critical gap in the development of technically easy, feasible as well as economically appealing biocatalytic methods. Aside from the particular operation, another essential feature for appealing biocatalysts is a cost-effective manufacturing process. When it comes to decade-long the biotransformations using wild-type species, the criterion has undoubtedly been a limiting factor and disadvantage in enzymatic chemistry. The use of wild-type species has significant disadvantages, such as the low expression of the desired protein, which necessitates a large amount of biomass for biotransformation (Nestl et al., 2014; Winkler et al., 2012). The major impact of side reactions is another consequence of lower protein expression of desired enzyme in wild-type microorganisms. Because of breakthroughs in molecular biology related to protein engineering, Enzymes can now (mostly) be obtained in recombinant form.

\section{Fermentation's Development and the First Microbial Transformations}

Through using biotransformations was the discovery of the synthesis of ethanol from glucose. Whole microorganisms cells including yeasts Schizosaccharomyces pombe, Saccharomyces cerevisiae as well as the bacterial cells producer like Zymomonasmobilis, have been used in these processes. Furthermore, use of the $\alpha$-amylase for starch saccharification dates back around 5000 years in the Egypt or Mesopotamia, when it was used to 
make beer. The development of cheese from milk held in stomach of the sheep is another earlier enzyme-catalyzed process (Kroutil et al., 2013; Scheller et al., 2014). Even though the existence and function of this enzyme, chymosin, were unknown at the time, people may use it for a variety of purposes. Since microorganisms have been the primary source of enzymes, the historical production of enzymatic synthesis has been closely linked to the advancement of microbiology.

The microbial-based biotransformation was done by Knoll AG on an industrial level in the 1930s. It was the synthesis of intermediate for L-ephedrine ((1S,2S)-2-methylamino-1-phenyl-propane-1-ol). Lephedrine and pseudoephedrine both are medicinally used to prevent low blood pressure and they also work as bronchodilators. Pharmaceutically they play a role as decongestants as well as anti-asthmatics (Figure 4).

\section{Formation of Biocatalytically Synthesized Intermediates}

The formation of catalytically synthesized intermediates i.e L-phenylacetylcarbinol and its Denantiomer takes place with the help of microorganisms. A condensation process of active acetaldehyde that is derived from pyruvic acid and benzaldehyde is added externally, along with microorganisms' yeasts like Saccharomyces cerevisiae and Candidautilis are used and this form the basis for the synthesis of catalytically synthesized intermediates (Gelalcha, 2014; Ku;lig et al., 2012).

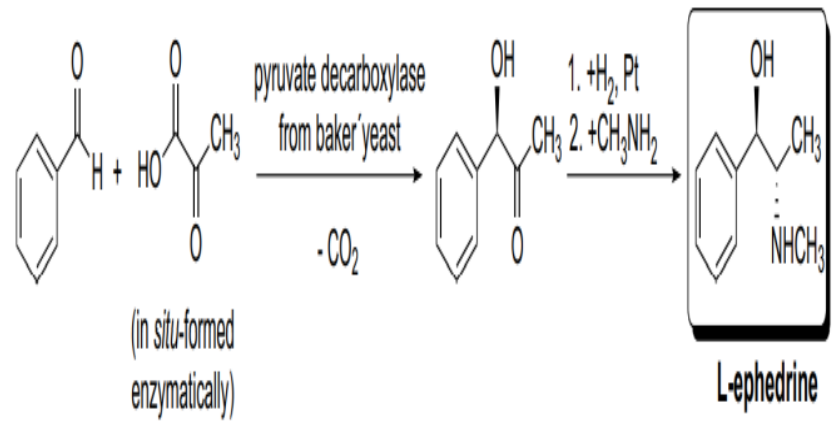

Figure 4. Formaion of L-ephedrine

In biocatalytic organic synthesis, the conversion of acrylonitrile with the aid of enzyme nitrile hydrase into acrylamide is a big achievement.

Nitrile

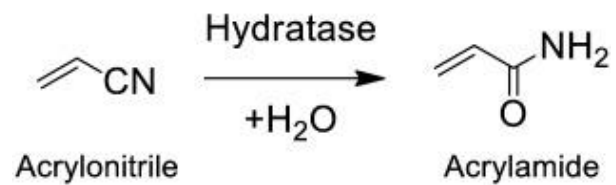

Figure 5. Conversion of acrylonitrile to acrylamide
This biocatalytic conversion is now an industrial production process and yields about 400000 tons of acrylamide annually (Figure 5).

An well-dressed example for using immobilized or wild-type microorganisms in the production of nonproteinogenic amino acids shows the biocatalytic synthesis for semisynthetic b-lactam side-chain D-phydroxyphenylglycine (Guo et al., 2018; Schober and Feber, 2013). The compound b-lactam side-chain Dp-hydroxyphenylglycine is used to prepare amoxicillin (a commercial semisynthetic antibiotic)

\section{Conclusion}

In conclusion, enzyme biocatalysis has now become an attractive biosynthetic method of organic chemistry in recent decades as a result of remarkable interactions among chemistry, biology, and engineering, thus complementing established classic chemical and biochemocatalytic approaches. final thoughts In terms of selectivity, yield, and conversion, it has been observed that using enzymes in the above-mentioned techniques provides efficient organic synthesis. At the same time, it overcomes the disadvantages of traditional enzyme-based approaches.

\section{Conflict of interest}

The authors declared absence of conflict of interest.

\section{References}

Greoger, H. (2010) in Catalytic Asymmetric Synthesis, 3rd edn (ed. I. Ojima), John Wiley \& Sons, Inc., Hoboken, ch. 6, pp. 269-341.

Fischer, E. (1894) Ber. Dtsch. Chem. Ges., 27, 29852993. Structure of enzyme catalysis and its specific properties.

Boesten, W. H. J., Broxterman, Q. B., Roos, E. C., Kaptein, B., Van den Tweel, W. J. J., Kamphuis, J., ... \& Schoemaker, H. E. (1997). Application of enzymes in industrial organic synthesis. Chimia 5. 308-310

Drauz, K., Gröger, H., \& May, O. (Eds.). (2012). Enzyme Catalysis in Organic Synthesis, 3 Volume Set (Vol. 1). John Wiley $\&$ Sons.

Chenault, H. K., Simon, E. S., \& Whitesides, G. M. (1988). Cofactor regeneration for enzymecatalyzed synthesis. Biotechnology and Genetic Engineering Reviews, 6(1), 221-270.

Marulanda, V. A., Gutierrez, C. D. B., \& Alzate, C. A. C. (2019). Thermochemical, Biological, Biochemical, and Hybrid Conversion Methods of Bio-derived Molecules into Renewable Fuels. In Advanced Bioprocessing for Alternative Fuels, Biobased Chemicals, and Bioproducts (pp. 59-81). Woodhead Publishing. 
Suresh, S., Viswanathan, V., Angamuthu, M., Dhakshinamoorthy, G. P., Gopinath, K. P., \& Bhatnagar, A. (2021). Lignin waste processing into solid, liquid, and gaseous fuels: a comprehensive review. Biomass Conversion and Biorefinery, 1-39.

Delimanto, W. O. (2020, June). Production of Bioethanol from Napier grass: Comparison in Pre-treatment and Fermentation Methods. In IOP Conference Series: Earth and Environmental Science (Vol. 520, No. 1, p. 012005). IOP Publishing.

Aui, A., Wang, Y., \& Mba-Wright, M. (2021). Evaluating the economic feasibility of cellulosic ethanol: A meta-analysis of technoeconomic analysis studies. Renewable and Sustainable Energy Reviews, 145, 111098.

Silva, C., Cavaco-Paulo, A. M., \& Fu, J. J. (2015). Enzymatic biofinishes for synthetic textiles (pp. 153-191). Woodhead Publishing: Cambridge.

Pera, L. M., Baigori, M. D., Pandey, A., \& Castro, G. R. (2015). Biocatalysis. In Industrial Biorefineries \& White Biotechnology (pp. 391408). Elsevier.

Paul, P. E. V., Sangeetha, V., \& Deepika, R. G. (2019). Emerging trends in the industrial production of chemical products by microorganisms. In Recent developments in applied microbiology and biochemistry (pp. 107-125). Academic Press.

Lange, L., Parmar, V., \& Meyer, A. (2017). Biocatalysis. In Encyclopedia of Sustainable Technologies (pp. 663-673). Elsevier.

Kulig, J., Simon, R. C., Rose, C. A., Husain, S. M., Häckh, M., Lüdeke, S., ... \& Rother, D. (2012). Stereoselective synthesis of bulky 1, 2diols with alcohol dehydrogenases. Catalysis Science \& Technology, 2(8), 1580-1589.

Guo, X., Okamoto, Y., Schreier, M. R., Ward, T. R., \& Wenger, O. S. (2018). Enantioselective synthesis of amines by combining photoredox and enzymatic catalysis in a cyclic reaction network. Chemical Science, 9(22), 5052-5056.

Schober, M., \& Faber, K. (2013). Inverting hydrolases and their use in enantioconvergent biotransformations. Trends biotechnology, 31(8), 468-478.

Gröger, H., May, O., Werner, H., Menzel, A., \& Altenbuchner, J. (2006). A "second-generation process" for the synthesis of Lneopentylglycine: asymmetric reductive amination using a recombinant whole cell catalyst. Organic process research \& development, 10(3), 666-669.
Gelalcha, F. G. (2014). Biomimetic Iron-Catalyzed Asymmetric Epoxidations: Fundamental Concepts, Challenges and Opportunities. Advanced Synthesis \& Catalysis, 356(2-3), 261-299.

Scheller, P. N., Fademrecht, S., Hofelzer, S., Pleiss, J., Leipold, F., Turner, N. J., ... \& Hauer, B. (2014). Enzyme toolbox: novel enantiocomplementary imine reductases. ChemBioChem, 15(15), 22012204.

Kroutil, W., Fischereder, E. M., Fuchs, C. S., Lechner, H., Mutti, F. G., Pressnitz, D., ... \& Siirola, E. (2013). Asymmetric preparation of prim-, sec-, and tert-amines employing selected biocatalysts. Organic process research \& development, 17(5), 751-759.

Hall, M., \& Bommarius, A. S. (2011). Enantioenriched compounds via enzymecatalyzed redox reactions. Chemical reviews, 111(7), 4088-4110.

Winkler, C. K., Tasnádi, G., Clay, D., Hall, M., \& Faber, K. (2012). Asymmetric bioreduction of activated alkenes to industrially relevant optically active compounds. Journal of biotechnology, 162(4), 381-389.

Nestl, B. M., Hammer, S. C., Nebel, B. A., \& Hauer, B. (2014). New generation of biocatalysts for organic synthesis. Angewandte Chemie International Edition, 53(12), 3070-3095.

De Wildeman, S. M., Sonke, T., Schoemaker, H. E., \& May, O. (2007). Biocatalytic reductions: from lab curiosity to "first choice". Accounts of Chemical Research, 40(12), 1260-1266.

Hollmann, F., Arends, I. W., \& Holtmann, D. (2011). Enzymatic reductions for the chemist. Green Chemistry, 13(9), 2285-2314.

May, O., Verseck, S., Bommarius, A., \& Drauz, K. (2002). Development of dynamic kinetic resolution processes for biocatalytic production of natural and nonnatural L-amino acids. Organic Process Research \& Development, 6(4), 452-457.

May, O., Nguyen, P. T., \& Arnold, F. H. (2000). Inverting enantioselectivity by directed evolution of hydantoinase for improved production of L-methionine. Nature biotechnology, 18(3), 317-320.

Gröger, H., Borchert, S., Kraußer, M., \& Hummel, W. (2009). Enzyme-Catalyzed Asymmetric Reduction of Ketones. Encyclopedia of Industrial Biotechnology: Bioprocess, Bioseparation, and Cell Technology, 1-16.

Kataoka, M., Kita, K., Wada, M., Yasohara, Y., Hasegawa, J., \& Shimizu, S. (2003). Novel

[Citation: Yaseen, F., Siddque, A., Idrees, N., Fateh, A., Ahmad, R., Ali, A., Ali, I. (2021). Enzyme biocatalysis in organic synthesis. Biol. Clin. Sci. Res. J., 2021: 73. doi: https://doi.org/10.54112/bcsrj.v2021i1.73] 
bioreduction system for the production of chiral alcohols. Applied Microbiology and Biotechnology, 62(5), 437-445.

Kizaki, N., Yasohara, Y., Hasegawa, J., Wada, M., Kataoka, M., \& Shimizu, S. (2001). Synthesis of optically pure ethyl (S)-4-chloro-3hydroxybutanoate by Escherichia coli transformant cells coexpressing the carbonyl reductase and glucose dehydrogenase genes. Applied Microbiology and Biotechnology, 55(5), 590-595.

Galkin, A., Kulakova, L., Yoshimura, T., Soda, K., \& Esaki, N. (1997). Synthesis of optically active amino acids from alpha-keto acids with Escherichia coli cells expressing heterologous genes. Applied and Environmental Microbiology, 63(12), 4651-4656.

\section{(c) (7) (9)}

Open Access This article is licensed under a Creative Commons Attribution 4.0 International License, which permits use, sharing, adaptation, distribution and reproduction in any medium or format, as long as you give appropriate credit to the original author(s) and the source, provide a link to the Creative Commons licence, and indicate if changes were made. The images or other third party material in this article are included in the article's Creative Commons licence, unless indicated otherwise in a credit line to the material. If material is not included in the article's Creative Commons licence and your intended use is not permitted by statutory regulation or exceeds the permitted use, you will need to obtain permission directly from the copyright holder. To view a copy of this licence, visit http://creativecommons.org/licen ses/by/4.0/.

(C) The Author(s) 2021

[Citation: Yaseen, F., Siddque, A., Idrees, N., Fateh, A., Ahmad, R., Ali, A., Ali, I. (2021). Enzyme biocatalysis in organic synthesis. Biol. Clin. Sci. Res. J., 2021: 73. doi: https://doi.org/10.54112/bcsrj.v2021i1.73] 